\title{
Synthesis of 1-3
}

(S,S,S)-Cyclohexane-cis, cis-1,3,5-tricarboxylic acid tris(1-carboxy-3-methylsulfanylpropyl) amide (1)

Cis,cis-1,3,5-cyclohexanetricarbonyl trichloride ${ }^{1}(1.40 \mathrm{~g}, 5.2 \mathrm{mmol})$ in dry $\mathrm{CH}_{2} \mathrm{Cl}_{2}$ (15 ml) was added to a solution of HCl.L-Met-OMe $(3.20 \mathrm{~g}, 16.1 \mathrm{mmol})$ and $\mathrm{Et}_{3} \mathrm{~N}(4.5 \mathrm{ml}, 32.8 \mathrm{mmol})$ in dry $\mathrm{CH}_{2} \mathrm{Cl}_{2}\left(200 \mathrm{ml}, \mathrm{T}=0{ }^{\circ} \mathrm{C}\right)$. The solution was slowly brought back to room temperature and left stirring overnight. The precipitate formed was collectd on a filter, rinsed with ethanol, and dried in a vacuum oven to give $2.96 \mathrm{~g}$ (4.54 mmol, 87\%) of the trimethyl ester of $\mathbf{1}$. For the hydrolysis, aqueous $\mathrm{NaOH}(15$ $\mathrm{ml} ; 2 \mathrm{M})$ was added to a cooled $\left(0^{\circ} \mathrm{C}\right)$ suspension of the trimethyl ester $(1.50 \mathrm{~g} ; 2.3$ $\mathrm{mmol})$ in $\mathrm{MeOH}(30 \mathrm{~mL})$. The mixture was slowly brought back to room temperature and stirred for 20 hours. After $20 \mathrm{~h}$ a clear solution was obtained, which was diluted with water $(50 \mathrm{ml})$, and acidified with $2 \mathrm{M} \mathrm{HCl}$ to $\mathrm{pH}<3$. The precipitate that has formed was collected on a filter, rinsed with ethanol, and dried in the vacuum oven to give pure 1. Yield: $91 \%$ (1.27 g; $2.1 \mathrm{mmol}) .{ }^{1} \mathrm{H}-\mathrm{NMR}: \delta=1.45$ (br, q, 1H), 1.71-2.03 (br. m, 4H), 2.03 (s, 3H), 2.30 (br. m, 2H), 3.40 (br. s, OH, 1H), 4.30 (m, 1H), 8.10 (d, 1H). ${ }^{13} \mathrm{C}-\mathrm{NMR}: \delta=13.57,28.71,29.57,30.28,41.34,49.66,172.40,173.41$. EI-MS for $\mathrm{C}_{24} \mathrm{H}_{39} \mathrm{~N}_{3} \mathrm{O}_{9} \mathrm{~S}_{3}$ calcd. 609.18; found $610\left[\mathrm{M}^{+}\right]$; $[\alpha]_{\mathrm{D}}{ }^{20}$ (c=1, DMSO) -13.5 ${ }^{\circ}$; Anal. for $\mathrm{C}_{24} \mathrm{H}_{39} \mathrm{~N}_{3} \mathrm{O}_{9} \mathrm{~S}_{3} \cdot 2.5 \mathrm{H}_{2} \mathrm{O}$ calcd. C $44.02 \mathrm{H} 6.77 \mathrm{~N} 6.42$; found $\mathrm{C} 43.89 \mathrm{H} 6.88 \mathrm{~N}$ 6.26.

(S,S,S)-Cyclohexane-cis,cis-1,3,5-tricarboxylic acid tris-(1-(2-hydroxyethoxycarbonyl)-2-phenyl-ethyl) amide (2)

$(S, S, S)$-Cyclohexane-cis,cis-1,3,5-tricarboxylic acid tris-(1-carboxy-2-phenylethyl) amide (0.49 g, $0.74 \mathrm{mmol}$, prepared as described for 1, starting from HCl.LPhe-OMe and Cis, cis-1,3,5-cyclohexanetricarbonyl trichloride) was suspended in ethylene glycol $(60 \mathrm{ml})$, and a few drops of concentrated $\mathrm{HCl}$ were added. The mixture was stirred at $135{ }^{\circ} \mathrm{C}$ for $3 \mathrm{~h}$, after which the now clear solution was cooled to $-20{ }^{\circ} \mathrm{C}$. The precipitate that has formed was collected on a filter, washed with water and acetone, and finally dried in vacuo to give pure 5c. Yield: 59\% (0.36 g, 0.46 mmol). ${ }^{1} \mathrm{H}-\mathrm{NMR}: \delta=1.24(\mathrm{~m}, 3 \mathrm{H}), 1.51(\mathrm{~m}, 3 \mathrm{H}), 2.19(\mathrm{~m}, 3 \mathrm{H}), 2.89$ and $3.05(2 \mathrm{x}$ br. $\mathrm{AB}, 2 \times 3 \mathrm{H}), 3.53(\mathrm{~m}, 6 \mathrm{H}), 4.05(\mathrm{~m}, 6 \mathrm{H}), 4.46(\mathrm{~m}, 3 \mathrm{H}), 4.81(\mathrm{t}, 3 \mathrm{H}), 7.22(\mathrm{~m}, 15 \mathrm{H})$, $8.18(\mathrm{~d}, 3 \mathrm{H}) .{ }^{13} \mathrm{C}-\mathrm{NMR}: \delta=29.94,35.52,41.01,52.18,57.73,65.16,125.42,127.10$, 127.97, 136.27, 170.68, 173.19. EI-MS for $\mathrm{C}_{42} \mathrm{H}_{51} \mathrm{~N}_{3} \mathrm{O}_{12}$ calcd. 789.3; found 812.2 $[\mathrm{M}+\mathrm{Na}]^{+} .[\alpha]_{\mathrm{D}}{ }^{20}(\mathrm{c}=1.06, \mathrm{DMSO})-7.5^{\circ}$; Anal for $\mathrm{C}_{42} \mathrm{H}_{51} \mathrm{~N}_{3} \mathrm{O}_{12} \cdot 0.5 \mathrm{H}_{2} \mathrm{O}$ calcd. C 63.14 H 6.56 N 5.26; found C 62.98 H 6.52 N 5.27.

(S,S,S)-Cyclohexane-cis,cis-1,3,5-tricarboxylic acid tris-(\{1-[2-(2-hydroxy-ethoxy)ethylcarbamoyl]-2-phenyl-ethyl\}-amide) (3)

Cis, cis-1,3,5-cyclohexanetricarbonyl trichloride $(0.40 \mathrm{~g}, 1.47 \mathrm{mmol})$ in dry $\mathrm{CH}_{2} \mathrm{Cl}_{2} \quad(5 \mathrm{ml})$ was added dropwise to a solution of xTFA.LPheNHCH${ }_{2} \mathrm{CH}_{2} \mathrm{OCH}_{2} \mathrm{CH}_{2} \mathrm{OH}(3.01 \mathrm{~g}, 4.40 \mathrm{mmol})$ and $\mathrm{Et}_{3} \mathrm{~N}(2.9 \mathrm{ml}, 20.8 \mathrm{mmol})$ in dry $\mathrm{CH}_{2} \mathrm{Cl}_{2}\left(100 \mathrm{ml}, \mathrm{T}=0{ }^{\circ} \mathrm{C}\right)$. The solution was slowly brought back to room temperature and stirred overnight. The precipitate that has formed was collected by filtration, washed with ethanol, and finally purified by precipitation from water followed by drying in a vacuum oven. Yield: $0.78 \mathrm{~g}(0.85 \mathrm{mmol}, 57 \%) .{ }^{1} \mathrm{H}-\mathrm{NMR}: \delta=$ 1.13 (br. q, 3H), 1.39 (br. d, 3H), 2.17 (br. t, 3H), 2.74 (t, 3H), 2.92 (d, 3H), 3.21 (m,

[1] K. Hanabusa, A. Kawakami, M. Kimura, H. Shirai, Chem. Lett. 1997, 191-192. 
6H), $3.40(\mathrm{~m}, 12 \mathrm{H}), 3.49(\mathrm{~m}, 6 \mathrm{H}), 4.46(\mathrm{~m}, 3 \mathrm{H}), 4.59$ (t, 3H), 7.21 (br. m, 15H), 7.98 $(\mathrm{d}, 3 \mathrm{H}), 8.05(\mathrm{~m}, 1 \mathrm{H}) .{ }^{13} \mathrm{C}-\mathrm{NMR}: \delta=30.07,41.02,52.52,59.14,67.84,71.11,125.14$, $126.88,128.12,136.83,170.32,172.92,213.09$. EI-MS for $\mathrm{C}_{48} \mathrm{H}_{66} \mathrm{~N}_{6} \mathrm{O}_{12}$ calcd. 918.47; found $919.6\left[\mathrm{M}+\mathrm{H}^{+}\right] . \quad[\alpha]_{\mathrm{D}}{ }^{20} \quad(\mathrm{c}=1.09$, DMSO $) \quad 2.5^{\circ} ;$ Anal. for $\mathrm{C}_{48} \mathrm{H}_{66} \mathrm{~N}_{6} \mathrm{O}_{12} \cdot \mathrm{H}_{2} \mathrm{O}$ calcd. C $61.52 \mathrm{H} 7.31 \mathrm{~N}$ 8.97, found C 61.57 H 7.40 N 8.94.

\section{Preparation of the gels}

Temperature-induced gelation: The gel sample was prepared by heating the gelator $(0.5-5 \mu \mathrm{mol})$ and surfactant $(0.5-35 \mu \mathrm{mol})$ in $1 \mathrm{~mL}$ of water (Millipore) in a closed vial until a clear solution was obtained. Cooling to room temperature caused the formation of clear gels.

pH-induced gelation (only applicable to 1$)$ : The gelator $(0.5-5 \mu \mathrm{mol})$ was dissolved in $0.1 \mathrm{M} \mathrm{NaHCO}_{3}(250 \mu \mathrm{L})$, an aliquot of an aqueous surfactant solution $(50-100 \mathrm{mM})$, and eventually the fluorescence probe $(10 \mu \mathrm{l}$ of a $0.02 \mathrm{M}$ stock solution of ANS in ethanol) were added, and gelation was induced by addition of $0.1 \mathrm{M} \mathrm{HCl}(250 \mu \mathrm{L})$.

\section{Cryo TEM}

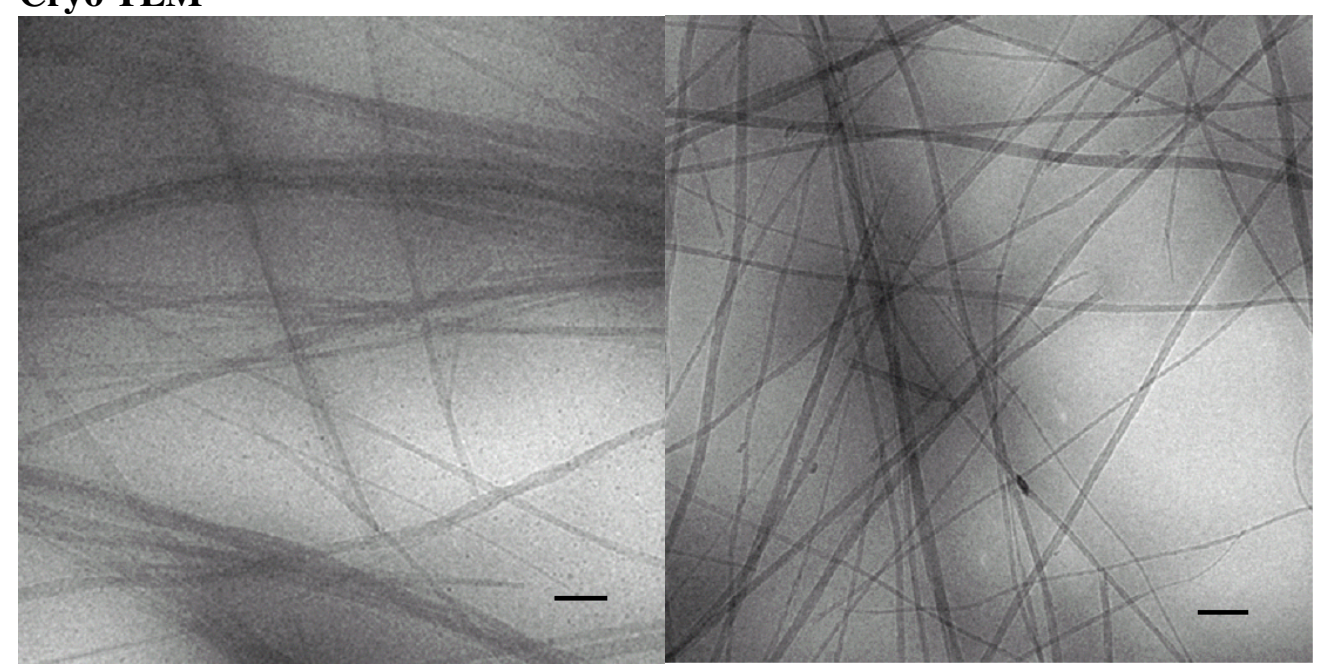

Cryo TEM of a hydrogel of $\mathbf{1}(3.3 \mathrm{mM})$ alone (left), and of a hydrogel of $\mathbf{1}$ (3.3 mM) with OG (33 mM, right). The scale bar is $300 \mathrm{~nm}$. 